\title{
PEDAGOGICAL CONDITIONS OF EDUCATION OF TOLERANCE IN STUDENTS OF PEDAGOGICAL COLLEGES IN OUT-OF-COURSE ACTIVITIES
}

\author{
Ivanna Tarhonii ${ }^{1}$ \\ ${ }^{1}$ Departments of Theory and Methods of Education, Rivne State Humanitarian University, Rivne, Ukraine \\ ivanca18@ukr.net \\ ORCID: http://orcid.org/0000-0002-0478-9235
}

ABSTRACT

Article history:

Received date 02.04.2020

Accepted date 25.04.2020

Published date 30.04.2020

Section:

Professional Development

D O I

10.21303/2313-8416.2020.001280

KEYWORDS

tolerance

education of tolerance

students of pedagogical colleges

hours of mentor of student group

pedagogical conditions

extracurricular activities
Object of research: Pedagogical conditions for the development of tolerance in students of teacher training colleges in extracurricular activities

Solved problem: Attracting students of pedagogical colleges to such activities as: research, artistic and aesthetic, value-oriented, organizational and managerial allowed creating the conditions necessary for developing cooperation skills, harmonizing different views, self-orientation in a given situation. The urgency of the problem of promoting tolerance among students of teacher training colleges, since the spiritual revival of modern Ukrainian society depends on future teachers.

The main scientific results: According to the results of the seminar "To increase the tolerance of future teachers", the vast majority of mentors of student groups found a high level of readiness to cultivate tolerance among students of teacher training colleges (75.0\%). For example, conducting a training lesson "What is tolerance?" aimed: to bring students closer to a deeper understanding of the "tolerance" phenomenon; contribute to improving student relationships on the principles of tolerance. Such forms as discussions turned out to be effective ("Why is it difficult to be tolerant in our life?", "Yes and no", etc.), Classes with training elements ("What is tolerance?", "Life tree", "Seven areas of tolerance training"); project activities, video presentations, dramas, the solution of problem situations and the use of reflective, empathic, dialogical techniques and the like.

The field of practical use of the research results: Attracting students of pedagogical colleges to such activities as: research, artistic and aesthetic, value-oriented, organizational and managerial allowed creating the conditions necessary for developing cooperation skills, harmonizing different views, self-orientation in that or other situation.

Innovative technological product: The pedagogical conditions for the development of tolerance among students of teacher training colleges in extracurricular activities are characterized, namely: the methodological preparation of mentors of student groups for the education of tolerance among students of teacher training colleges; substantial and methodological support of the process of cultivating tolerance among students of teacher training colleges; attracting students of teacher training colleges to socio-cultural activities aimed at promoting tolerance.

The scope of the innovative technological product: The material of the article can be used by mentors of student groups of teacher training colleges, as well as curators and students of higher educational institutions.

(C) The Author(s) 2020. This is an open access article under the CC BY license http://creativecommons.org/licenses/by/4.0).

\section{Introduction}

\section{1. The object of research}

Pedagogical conditions for the development of tolerance in students of teacher training colleges in extracurricular activities.

\section{2. Description of the problem}

In modern conditions, the problem of cultivating tolerance among students is becoming especially relevant, since the aggravation of crisis phenomena in modern society has led to a change 
in life values and ideals, it turns out to be a manifestation of disrespect, intolerance, aggressiveness, violence to another point of view.

In this context, the issue of promoting tolerance among students of teacher training colleges is becoming urgent, since the spiritual revival of modern Ukrainian society depends on future teachers.

In state documents, in particular, the Laws of Ukraine "On Education" (2017), "On Higher Education" (2014), the National Strategy for the Development of Education in Ukraine for the period up to 2012 (2013), the Concept of National-Patriotic Education of Children and Youth (2015) the importance of moral education of student youth and then the education of tolerance is noted.

\section{3. Suggested solution to the problem}

Various aspects of the problem of education of tolerance in extracurricular activities are reflected in the writings of scientists and teachers, namely: the technology of education of tolerance (O. Bogdanova [1], L. Kanyshevska [2], I. Sukhopara [3], N. Chepel [4], S. Zhang [5] and others. In particular, E. Bogdanova considers pedagogical tolerance as the basis for the implementation of pedagogical partnerships [1]. L. Kanyshevska explores the theoretical and methodological foundations of social maturity education high school graduate boarding schools in extracurricular activities [2]. Group work as a factor in the formation of tolerance in primary school students in extracurricular activities is studied by I. Sukhopara [3]. The formation of ethnic tolerance of students in higher education is studied by M. Chepel. She establishes that the problem of tolerance and ethnic tolerance in particular, today it is one of the central problems of both global and national order [4]. Researcher S. Zhang considers the formation of ethnic tolerance among students on the basis of multiculturalism [5].

So, despite the wide reflection of the problem in specialized literature, such an aspect of it as the education of tolerance among students of teacher training colleges did not find wide coverage.

The aim of this article is to characterize the pedagogical conditions for the development of tolerance among students of teacher training colleges in extracurricular activities.

\section{Materials and Methods}

Let's characterize the pedagogical conditions for the cultivation of tolerance among students of teacher training colleges in extracurricular activities.

In the pedagogical literature, the conditions for the effectiveness of activities are defined as objective and subjective prerequisites, the implementation of which allows to achieve the intended goal with the most rational (optimal) use of forces and means. The implementation of the conditions is in the "successful solution of pedagogical problems, in the appropriate use of means and methods to achieve goals" [6, p. 54].

In the context of our study, pedagogical conditions are defined as “... an essential component of the pedagogical process, which includes the content, methods, organizational forms of education, and therefore focused on the inner world of the pupil" [7, p. 179].

The analysis of pedagogical literature, the study of the state of tolerance education among students of pedagogical colleges made it possible to determine pedagogical conditions that increase the effectiveness of tolerance education for the above-mentioned contingent of higher education applicants in extracurricular activities, namely: methodological preparation of mentors of student groups for the education of tolerance in students of pedagogical colleges; substantial and methodological support of the process of cultivating tolerance among students of teacher training colleges; attracting students of teacher training colleges to socio-cultural activities aimed at promoting tolerance.

One of the pedagogical conditions for the cultivation of tolerance among students of pedagogical colleges is the methodological preparation of mentors of student groups for the cultivation of tolerance among students of pedagogical colleges.

The mentor of the student group performs many functions, among which let's highlight: organizational, information and communication, security, motivational, stimulating, guiding, analytical, coordination, prognostic, preventive, heuristic [8, p. 131].

Researcher N. Kuzmina defines a number of skills that a student group mentor must have in order to effectively carry out its activities: 
- epistemological ability (to replenish one's knowledge with new scientific data (on methods of upbringing) and anticipate one's activity; analyze one's own activity; analyze the pedagogical situation and calculate the impact on students; perceive and take into account the students'reaction to their activity and rebuild it in the future, take into account their recommendations of psychological and pedagogical theory; to form new pedagogical knowledge);

- design skills (to design educational activities for the entire time working with the student group, taking into account future prospects and possible results; to design educational impacts taking into account the future profession of students; to design work in the student group taking into account the interests of students; to design ways to organize students' independent work in educational activities; design ways to organize various types of student activities);

- constructive skills (to select and compositionally interesting to build the content of extracurricular activities, use the traditions of the institution, its history in working with the student group; involve in the work with a group of interesting people, activate students to take the initiative to conduct interesting meetings, discussions, discussions [9, p. 203-204].

The key role in the cultivation of tolerance among students of teacher training colleges is played by the mentor of the student group, since only a tolerant teacher is able to educate a tolerant student.

Researcher O. Bogdanova considers pedagogical tolerance as the ability to construct peerto-peer visually-sensitive with other participants in the educational process [1].

Let's adhere to the opinion of L. Baiborodova that the signs of a tolerant teacher are: of others;

- cooperation with others through partnerships; willingness to listen and hear the opinions

- respect for the right of others to individuality and identity; tolerance for other people's opinions, beliefs, behavior;

- ability to look at a problem through the eyes of others;

- recognition of diversity;

- awareness of actions;

- emotional poise;

- constructive criticism;

- avoidance of violence;

- ability to take responsibility for decisions made;

- ability to analyze their actions with their subsequent correction [10, p. 36].

\section{1. Experimental procedures}

In order to increase the level of readiness of mentors of student groups to cultivate tolerance among students of pedagogical colleges, a seminar program was developed "We increase tolerance among future teachers" (18 hours).

The main objectives of the seminar: to deepen the knowledge of mentors of student groups about the essence of the concept of "tolerance"; actualize the problem of promoting tolerance among students of teacher training colleges in extracurricular activities; to expand the knowledge of mentors of student groups about pedagogical tolerance; to consider the features of promoting tolerance in the above contingent of applicants for higher education; to acquaint the mentors of student groups with the diagnosis of the levels of upbringing of tolerance among students of teacher training colleges; deepen the knowledge of mentors of student groups about the forms and methods of promoting tolerance; contribute to the formation of subject-subject relations between teachers and students.

Let's cite the topics of the seminar for mentors of student groups "Growing tolerance among future teachers": "Tolerance as a pedagogical category", "Essential characteristic of the concept of "tolerance of students of pedagogical colleges", "Optimization of forms and methods of cultivating tolerance of students of pedagogical colleges in extracurricular activities" (lectures) "Growing tolerance", "Pedagogical tolerance", "Features of the education of tolerance in students of teacher training colleges in extracurricular activities", "Methods of diagnosis tolerance education levels of students of teacher training colleges", "Style of pedagogical communication", "Ways to prevent interpersonal conflicts" (interactive classes).

Work with mentors of student groups contributed to the identification of emotionally-positive motivation for the cultivation of tolerance among students of teacher training colleges; 
deepening knowledge about the essence and features of the education of tolerance among future teachers; mastering the appropriate forms and methods of promoting tolerance; the formation of a reflective position.

\section{Results}

According to the results of the seminar "Growing tolerance among future teachers", the vast majority of mentors of student groups found a high level of readiness to cultivate tolerance among students of teacher training colleges (75.0\%).

The next pedagogical condition for the cultivation of tolerance in students of teacher training colleges is the substantive and methodological support of the process of cultivating tolerance in students of teacher training colleges in extracurricular activities. The leading means of realizing this pedagogical condition was the development of the program of hours of the mentor of the student group "Step towards tolerance", the main tasks of which included:

- deepen the knowledge of students of teacher training colleges about the essence of the phenomenon of "tolerance" and about the quality of a tolerant person;

- promote awareness of the existence of the boundaries of tolerance;

- develop empathy;

- form skill: to reveal humanity, tolerance, goodwill, responsiveness, self-control; interact, collaborate and engage in dialogic communication; Find ways to prevent and resolve conflicts.

Each topic included as a kind of theoretical material aimed at deepening the knowledge of students of teacher training colleges regarding the essence of the concept of "tolerance" and material for practical work.

For example, conducting a training lesson "What is tolerance?" aimed: to bring students closer to a deeper understanding of the phenomenon of "tolerance"; contribute to improving student relationships on the principles of tolerance.

So, let's note that tolerance is a principle of a culture of peace; respect, perception and correct understanding of the rich worldview of the cultures of our world, our forms of self-expression and ways of manifesting human personality; recognition of universal human rights and freedoms; harmony in diversity; patience, restraint in relation to the characteristics of other people.

Students were asked to write their own definition of the concept of "tolerance", then this definition was discussed. So, students approached a deeper understanding of the concept of a problem, found the keywords that characterize this concept.

The expansion of the knowledge of students of pedagogical colleges about tolerant behavior was facilitated by the "Carousel" exercise [11, p. 81]. Students expressed their understanding of tolerant behavior. So, we nonverbally encouraged each student to tolerate communication.

\section{Discussion of the results}

In the classes with students of teacher training colleges, various methods turned out to be effective: stories, explanations, conversations, persuasions, examples, exercises, discussions, pedagogical requirements, creating and analyzing educational situations, brainstorming, business games ("White Crow", "Let Me Circle You", "I will take with me", "Personality is not personality", etc.).

Such forms as discussions turned out to be effective ("Why is it difficult to be tolerant in our life?", "Yes and no", etc.), Classes with training elements ("What is tolerance?", "Life tree", "Seven areas of tolerance training"); project activities, video presentations, dramas, the solution of problem situations and the use of reflective, empathic, dialogical techniques and the like.

The next pedagogical condition is to attract students of teacher training colleges to socio-cultural activities aimed at promoting tolerance.

In socio-cultural activities involved the essential forces of a person, its intellect, emotions, will, spirituality, the prerequisites are created not only for the formation of creativity, but also for its active manifestation, that is, enrichment of a person's social experience [12, p. 270].

Researcher Yu. Aksionov argues that the activities and relationships that develop in the process of its implementation can positively affect a person only when such an impact is accepted and penetrates into its need-motivational sphere. This process is only on condition that inclusion in collective activity contributes to one degree or another to meet certain personal needs, interests and requests of the participant of the activity [13, p. 42]. 
Let's adhere to the opinion of L. Kanyshevska, who argues that socio-cultural activities were: interesting and informal; important for students to relate to their interests; provide the opportunity to be implemented in it; heavy and at the same time feasible, since the success of its implementation should require a willpower; activity in which the student is faced with the choice of act [2, p. 254].

Attracting students of pedagogical colleges to such activities as: research, artistic and aesthetic, value-oriented, organizational and managerial has allowed to create the conditions necessary for developing cooperation skills, harmonizing different views, self-orientation in a given situation.

\section{Conclusions}

Summing up, let's note that we have characterized the pedagogical conditions for the development of tolerance among students of teacher training colleges in extracurricular activities, namely: the methodological preparation of mentors of student groups for the education of tolerance in students of teacher training colleges; substantial and methodological support of the process of cultivating tolerance among students of teacher training colleges; attracting students of teacher training colleges to socio-cultural activities aimed at promoting tolerance.

The problem of developing tolerance among students of teacher training colleges in extracurricular activities requires further, detailed and diverse research. In particular, the study of the potential for follow-up activities in this aspect.

\section{References}

[1] Bogdanova, E. L.; Kabrin, V. I. (Ed.) (2002). Ya i Drugoi: dialog ili konfrontatsiia? Lichnost v paradigmakh i metaforakh: mentalnost - kommunikatsiia - tolerantnost. Tomsk: Izdatelstvo Tomskogo universiteta, 192-202.

[2] Kanishevska, L. V. (2011). Teoretyko-metodychni osnovy vykhovannia sotsialnoi zrilosti starshoklasnykiv zahalnoosvitnikh shkil-internativ u pozaurochnii diialnosti. Kyiv, 491.

[3] Sukhopara, I. H. (2014). Hrupova robota yak chynnyk formuvannia tolerantnosti u molodshykh shkoliariv u pozaurochnii diialnosti. Mizhnarodni Chelpanivski psykholoho-pedahohichni chytannia, 12, 359-364. Available at: http://chelpanov.eeipsy.org/ index.php/eeip/issue/view/15/PDF12

[4] Czepil, M., Karpenko, O., Revt, A., Istomina, K. (2019). Formation of students' ethnic tolerance in institutions of higher education. Advanced Education, 12, 114-119. doi: http://doi.org/10.20535/2410-8286.168675

[5] Xiaoxing, Z. (2016). Ethnic tolerance formation of students on the principles of multiculturalism. The Modern Higher Education Review, 1, 141-147. doi: http://doi.org/10.28925/2518-7635.2016.1.16

[6] Kraevskii, V. V., Berezhnova, E. V. (2006). Metodologiia pedagogiki. Novii etap. Moscow: Akademiia, 400.

[7] Selevko, G. K. (1999). Tekhnologiia samorazvitiia lichnosti shkolnika. Shkolnye tekhnologii, 6, 5-26.

[8] Shelest, N. A. (2019). Formuvannia tsinnisnoho stavlennia do stvorennia simi u studentiv ahrarnykh koledzhiv u poza audytornii diialnosti. Kyiv, 280. Available at: https://nauka.udpu.edu.ua/wp-content/uploads/2019/03/Дисертація.Шелест.pdf

[9] Kuzmyna, N. V. (Ed.) (2002) Metodi systemnoho pedahohycheskoho yssledovanyia. Moscow: Narodnoe obrazovanye, 208.

[10] Baiborodova, L. V. (2007). Teoriia, metodika i praktika vzaimodeistviia v raznovozrastnykh gruppakh uchashchikhsia. Iaroslavl: Izd-vo IAGPU imeni K. D. Ushinskogo, 319.

[11] Kanishevska, L. V. (2011). Krokuiemo do sotsialnoi zrilosti. Kyiv: In-t problem vykhovannia NAPN Ukrainy, 175.

[12] Golovanova, N. F. (2005). Obshchaia pedagogika. Saint Petersburg: Rech, 317.

[13] Aksenov, Iu. M. (2003). Deiatelnostnii podkhod v sotsialno-vospitatelnoi rabote s trudnymi detmi. Moscow. 